\title{
Purification of inulinases by changing the ionic strength of the medium and precipitation with alcohols
}

\author{
SIMONE GOLUNSKI ${ }^{1,3}$, MARCELI F. SILVA ${ }^{1}$, CAMILA T. MARQUES ${ }^{3}$, VANUSA ROSSETO ${ }^{3}$, \\ ROSILENE R. KAIZER ${ }^{3}$, ALTEMIR J. MOSSI ${ }^{3}$, DIANE RIGO ${ }^{1}$, ROGÉRIO M. DALLAGO ${ }^{1}$, \\ MARCO DI LUCCIO ${ }^{2}$ and HELEN TREICHEL ${ }^{3}$ \\ ${ }^{1}$ Universidade Regional Integrada do Alto Uruguai e das Missões/URI, Departamento de Engenharia de \\ Alimentos, Campus de Erechim, Av. 7 de Setembro, 1621, 99700-000 Erechim, RS, Brazil \\ ${ }^{2}$ Universidade Federal de Santa Catarina, Departamento de Engenharia Química e de Alimentos, \\ Campus Reitor João David Ferreira Lima, s/n, 88800-000 Florianópolis, SC, Brazil \\ ${ }^{3}$ Programa de Pós-Graduação em Ciência e Tecnologia Ambiental, Universidade Federal da Fronteira \\ Sul, Campus de Erechim, Rodovia ERS 135, Km 72, 99700-970 Erechim, RS, Brazil
}

Manuscript received on June 9, 2016; accepted for publication on January 1, 2017

\begin{abstract}
The present study evaluated the purification of inulinase by changing the ionic strength of the medium by addition of $\mathrm{NaCl}$ and $\mathrm{CaCl}_{2}$ followed by precipitation with n-propyl alcohol or iso-propyl alcohol. The effects of the concentration of alcohols and the rate of addition of alcohols in the crude extract on the purification yield and purification factor were evaluated. Precipitation caused an activation of enzyme and allowed purification factors up to 2.4-fold for both alcohols. The purification factor was affected positively by the modification of the ionic strength of the medium to $0.5 \mathrm{~mol} . \mathrm{L}^{-1} \mathrm{NaCl}$ before precipitation with the alcohol (n-propyl or iso-propyl). A purification factor of 4.8 -fold and an enzyme yield of $78.1 \%$ could be achieved by the addition of $0.5 \mathrm{~mol} . \mathrm{L}^{-1}$ of $\mathrm{NaCl}$ to the crude extract, followed by the precipitation with 50 $\%(\mathrm{v} / \mathrm{v})$ of n-propyl alcohol, added at a flow rate of $19.9 \mathrm{~mL} / \mathrm{min}$.
\end{abstract}

Key words: inulinases, ionic strength, precipitation, low cost.

\section{INTRODUCTION}

Inulinases are classified among the hydrolases and are denominated as being 2,1- $\beta$-D-fructanfructanohydrolase (E.C: 3.2.1.7) (Cazetta et al. 2005, Singh and Chauhan 2017). These enzymes are useful for production of "inulooligosaccharides" and have functional and nutritional properties for use in lowcalorie diets, stimulation of Bifidus bacteria and as a source of dietary fiber in food preparations (Singh et al. 2007).

The isolation and purification of proteins are crucial processes in the production of biomolecules as enzymes, due to their wide range of applications in biomedical and food industries. Chromatography is the most used technique for enzyme purification (Abu El-Souod et al. 2014). This is a very specific and useful tool, although relatively costly and rather difficult to scale-up (Przybycien et al. 2004).

Correspondence to: Helen Treichel

E-mail: helentreichel@gmail.com 
Precipitation is a common approach to isolate and concentrate enzymes and other macromolecules. This technique offers the possibility of concentrating and purifying the target macromolecule usually at a low cost (Boeris et al. 2009, Soares et al. 2012). Precipitation should result both in concentration and in purification, but actually the former is more effectively achieved. Therefore, precipitation is frequently used in the first steps of downstream processing, concentrating the molecule of interest for subsequent purification steps. However, for extracellular enzymes, precipitation could be an effective way of achieving purification as well. Precipitation is advantageous for concentration and purification of enzymes, since this technique needs no interruption, requires simple equipment, and can be easily scaled up and used with different kinds of precipitants (Cortez and Pessoa 1999).

Purification processes using salts and solvents are extensively used in operations of concentration and pre-purification of proteins. A lot of precipitation techniques use to use ammonium sulfate as precipitant agent. However, there is not a universal protocol, so precipitation agents and process conditions should be determined experimentally for each system. The increment of ionic strength of the media using high salt concentrations could cause loss in the enzymatic activity. Organic solvents could be used in protein precipitation, but sometimes enzyme denaturation is observed. In both cases, the viability should be determined experimentally. There is a lack in the literature about systematic studies combining salt and organic solvents for protein separation (Cortez and 1999, Zhang et al. 2004, Trentini et al. 2015).

In this sense, the aim of this study was to develop a strategy of inulinase purification, based on the change in ionic strength of the medium by adding salts, followed by precipitation with different alcohols.

\section{MATERIALS AND METHODS}

PRODUCTION OF INULINASE FROM Kluyveromyces marxianus NRRL Y-7571

Inulinase was obtained by Kluyveromyces marxianus NRRL Y-7571 in solid-state fermentation of sugarcane bagasse. Sugarcane molasses (SCM, $15 \% \mathrm{wt} \%$ ), $30 \mathrm{wt} \%$ of corn steep liquor (CSL) and $20 \mathrm{wt} \%$ of soybean meal were added to the solid substrate as supplementation (Mazutti et al. 2006, 2007). Sugarcane bagasse was obtained in a local market, corn steep liquor from Corn Products International (Mogi Guaçu, SP, Brazil), sugarcane molasses from Refinaria Ester (Campinas, SP, Brazil) and soybean meal from Olfar (Erechim, RS, Brazil). Bagasse moisture was adjusted to $65 \%$ prior to the innoculation (Mazutti et al. 2006). Sugarcane molasses was pre-treated as described by Sguarezi et al. 2008.

Solid state fermentation was carried out in a cylindrical vessel $(34 \mathrm{~cm}$ diameter and $50 \mathrm{~cm}$ height) loaded with $3 \mathrm{~kg}$ of sugarcane bagasse containing $65 \%$ moisture, previously sterilized at $121{ }^{\circ} \mathrm{C}$ for 20 min, and inoculated with $765 \mathrm{~mL}$ of cell suspension (Mazutti et al. 2010). Humidified air was injected in the bioreactor during all fermentation run. After fermentation for $24 \mathrm{~h}$, the enzyme extracted from the bagasse with sodium acetate buffer pH $4.8100 \mathrm{mM}$ (Bender et al. 2008).

PRECIPITATION WITH ALCOHOL N-PROPYL AND ISO-PROPYL

The enzyme extract was centrifuged at $2,800 \times \mathrm{g}$ for $20 \mathrm{~min}$ at $5{ }^{\circ} \mathrm{C}$, and the supernatant was used for enzyme concentration. The alcohols (n-propyl alcohol or iso-propyl alcohol) were dropped into an aliquot of the crude enzyme extract at a determined feed rate and $5{ }^{\circ} \mathrm{C}$, controlled by a peristaltic pump (Masterflex). The resulting suspension was centrifuged at $9,000 \times \mathrm{g}$ for $15 \mathrm{~min}$ at $5{ }^{\circ} \mathrm{C}$, and the collected precipitate was dissolved in sodium acetate buffer pH $4.8100 \mathrm{mM}$. Enzyme activity was determined in all fractions. 
A central composite rotational design (CCRD) $2^{2}$ was used to assess the effects of alcohol concentration $(10-90 \%)$ and feed rate $(0.09-19.9 \mathrm{~mL} / \mathrm{min})$ on the degree of purification and yield. Level limits were chosen based on previous studies (Golunski et al. 2011). The results were analyzed using Statistica 8.0 (Stat Soft Inc. Tulsa, OK, USA).

\section{CHANGING THE IONIC STRENGTH OF THE MEDIUM}

Aiming at changing the ionic strength of the medium, $\mathrm{NaCl}$ and $\mathrm{CaCl}_{2}$ molarities in $0.05,0.1$ and 0.5 $\mathrm{mol} / \mathrm{L}$ were used. Each salt was added to the crude enzyme extract to the desired concentration, and after homogenization the samples were subjected to precipitation with alcohols (n-propyl or iso-propyl) under optimized conditions. After addition of alcohols, the resulting precipitate was centrifuged at $9000 \times \mathrm{g}$ for $15 \mathrm{~min}$ at $5{ }^{\circ} \mathrm{C}$. The precipitate was collected and dissolved in sodium acetate buffer $\mathrm{pH} 4.8100 \mathrm{mM}$. The enzyme activity and total protein were determined in all fractions.

\section{ANALYTICAL METHODS}

\section{Enzymatic activity}

Inulinase activity were determined as described elsewhere (Bender et al. 2008). An extract sample of $0.5 \mathrm{~mL}$ was added to $4.5 \mathrm{~mL}$ of a $2 \%$ (w/w) sucrose solution in sodium acetate buffer $100 \mathrm{mM} \mathrm{pH} 4.8$ and incubated at $50{ }^{\circ} \mathrm{C}$ for $10 \mathrm{~min}$. The resulting reducing sugars were determined by reaction with 3,5 dinitrosalicylic acid (DNS) (Miller 1959). One unit of inulinase activity is defined as the amount of enzyme necessary to hydrolyze $1 \mu \mathrm{mol}$ of sucrose per min at the reaction conditions. Following the same described above, the inulinase activity using inulin as substrate was also determined at some experimental conditions.

\section{Total protein determination}

Total protein was performed following the method described by Bradford 1976 using bovine serum albumin (BSA) as standard.

\section{Purification parameters}

The purification factor (PF) was defined as the ration between the specific activities of the enzyme (U/mg) in the resuspended precipitate and in the crude enzyme (U/mg), respectively. Enzyme activity yield (EA) was calculated as the ratio between the total activity in the precipitate and in the crude enzyme extract, respectively (Golunski et al. 2011).

\section{RESULTS AND DISCUSSION}

The results obtained in the precipitation of inulinase are presented in Table I. In this table, one can find the experimental design that were carried out (real and coded values) including the independent variables evaluated (concentration and flow rate of alcohol) and the respective obtained responses in terms of specific activity, enzyme yield and purification factor. The average specific activity of the crude extract was 78.1 U/ $\mathrm{mg}$. An increase in specific activity was observed after precipitation in most of the runs. The highest specific activity was found in run 8 (182 U/mg for the n-propyl alcohol and $195 \mathrm{U} / \mathrm{mg}$ for the iso-propyl alcohol). 
TABLE I

Matrix of the experimental design (coded and real values) and the responses in terms of specific activity; purification factor and activity yield for n-propyl alcohol and iso-propyl alcohol.

\begin{tabular}{|c|c|c|c|c|c|c|c|c|}
\hline \multirow[t]{2}{*}{ Run } & \multirow[t]{2}{*}{${ }^{*}$ Conc \% } & \multirow{2}{*}{$\begin{array}{l}\text { Flow rate } \\
\text { (mL/min) }\end{array}$} & \multicolumn{3}{|c|}{ n-propyl alcohol } & \multicolumn{3}{|c|}{ iso-propyl alcohol } \\
\hline & & & $\begin{array}{c}\text { Specific activity } \\
\text { (U/mg) }\end{array}$ & $\begin{array}{c}\text { Activity yield } \\
(\%)\end{array}$ & $\begin{array}{l}\text { Purification } \\
\text { factor (PF) }\end{array}$ & $\begin{array}{c}\text { Specific activity } \\
\text { (U/mg) }\end{array}$ & $\begin{array}{c}\text { Activity yield } \\
(\%)\end{array}$ & $\begin{array}{r}\text { Purification } \\
\text { factor (PF) }\end{array}$ \\
\hline $\begin{array}{l}\text { Crude } \\
\text { enzyme }\end{array}$ & - & - & 74.6 & 100 & 1.0 & 81.6 & 100 & 1.0 \\
\hline 1 & $-1(22)$ & $-1(2.97)$ & 100.9 & 41.7 & 1.3 & 41.0 & 21.9 & 0.5 \\
\hline 2 & $+1(78)$ & $-1(2.97)$ & 141.2 & 94.0 & 1.9 & 11.8 & 88.6 & 1.4 \\
\hline 3 & $-1(22)$ & $+1(17)$ & 152.6 & 42.3 & 2.0 & 48.3 & 27.3 & 0.6 \\
\hline 4 & $+1(78)$ & $+1(17)$ & 144.0 & 99.9 & 1.9 & 128.1 & 89.4 & 1.6 \\
\hline 5 & $-1.41(10)$ & $0(10)$ & 9.6 & 3.0 & 0.1 & 7.4 & 2.22 & 0.1 \\
\hline 6 & $+1.41(90)$ & $0(10)$ & 150.8 & 105.9 & 2.0 & 107.9 & 84.9 & 1.3 \\
\hline 7 & $0(50)$ & $-1.41(0.09)$ & 162.2 & 100.3 & 2.2 & 114.9 & 83.9 & 1.4 \\
\hline 8 & $0(50)$ & $+1.41(19.9)$ & 182.2 & 113.8 & 2.4 & 194.7 & 126.1 & 2.4 \\
\hline 9 & $0(50)$ & $0(10)$ & 159.1 & 100.0 & 2.1 & 151.0 & 98.2 & 1.8 \\
\hline 10 & $0(50)$ & $0(10)$ & 157.1 & 101.5 & 2.1 & 149.4 & 97.4 & 1.8 \\
\hline 11 & $0(50)$ & $0(10)$ & 157.0 & 99.4 & 2.1 & 151.2 & 100.0 & 1.8 \\
\hline
\end{tabular}

*Conc: concentration.

High yields were also found in run 8 (114 \% for the n-propyl alcohol and $126 \%$ for the iso-propyl alcohol). The lowest yield was obtained in run 5, at the lowest level of alcohol concentration and high addition rate, suggesting that low concentrations of alcohols are not effective for protein fractionation, or even that the high addition rate can cause enzyme denaturation.

For n-propyl alcohol, except from run 5, all runs yielded PF higher than 1, showing that precipitation could yield some degree of purification, depending on the concentration of the alcohol and its flow rate of addition to the crude extract. The highest purification factors were obtained in runs 7,8 and central points. For the precipitation with iso-propyl alcohol, runs 1, 3 and 5 yielded a PF less than 1, indicating that low concentrations of the alcohol are not effective for reaching any enzyme purification. The highest purification factors obtained with the precipitation with iso-propyl alcohol were observed in run 8 and in the central points.

It is worth mentioning that purification factors found here (around 2.4) are higher $(\cong 60 \%)$ than the ones usually presented in the literature $(\mathrm{PF}=1.75)$ using different solvents for enzymes precipitation (Zhao et al. 2011). Abu El-Souod et al. (2014) obtained a specific inulinase activity of $1915 \mathrm{U} / \mathrm{mg}$ protein which represented 2.65-fold purification over the crude inulinase extract with $42.8 \%$ recovery. In their work exoinulinase was purified by using ammonium sulfate precipitation followed by ion exchange chromatography on DEAE-cellulose. In a previous study of our research group, we found similar results using ethanol for precipitation of inulinases produced by K. marxianus (Golunski et al. 2011) and Singh et al. (2017) partially purified an inulinase extract by ethanol precipitation and gel exclusion chromatography. Under the optimized conditions maximum yield $65.5 \%$ of immobilized inulinase was obtained.

Empirical models for activity yield as a function of concentration and flow rate of the alcohols were built and validated by analysis of variance (ANOVA). A correlation coefficient of 0.98 for n-propyl alcohol and 0.96 for iso-propyl alcohol and a calculated F-test higher than the tabulated one were obtained, validating the models using $95 \%$ of confidence. 
Equation (1) and Equation (2) show that the concentration of alcohol, as well as the interaction between the alcohol concentration and the flow rate, are the factors that most affect activity yield. The dependence of yield on the interaction between the two factors shows that the precipitation process is complex, since the feed rate of the alcohols can increase or decrease the activity yield, depending on the concentration of the alcohols.

$$
\begin{aligned}
& Y_{C A L C, n^{-} \text {propyl alcohol }}=100.32+31.97 * C-25.87 * C^{2}+3.21 * F R+0.59 * F R^{2}+1.33 * C^{*} F R \\
& Y_{C A L C, \text { iso }{ }^{-} \text {propyl alcohol }}=98.63+30.76 * C-31.84 * C^{2}+8.85 * F R-1.80 * F R^{2}-1.15 * C^{*} F R
\end{aligned}
$$

where $\mathrm{Y}_{\mathrm{CALC}}$ is the calculated recovery yield of the enzyme (\%), C and FR are the coded concentration of the alcohols and flow rate, respectively.

Considering that the results obtained using iso-propyl and n-propyl alcohols were similar to a previous work of our research group, (Golunski et al. 2011) we decided to evaluate a combined strategy; i.e., to change the media ionic strength using different salts followed by precipitation with the alcohol. In the present study, we opted to use $50 \%$ of the alcohol in the further steps, since this concentration resulted in high activity yields and can be more cost effective than the use of higher concentrations.

The effect of changing ionic strength of the medium was assessed by adding different concentrations of $\mathrm{NaCl}$ and $\mathrm{CaCl}_{2}$ to the crude enzyme extract, followed by the precipitation with the alcohol. The results are summarized in Table II.

Most of the experiments showed a decrease on the total protein $(\mathrm{mg} / \mathrm{mL})$ and an increase in the total activity $(\mathrm{U} / \mathrm{mL})$ compared to the crude enzymatic extract, and consequently an increase in the specific activity $(\mathrm{U} / \mathrm{mg})$.

TABLE II

Effect of changing ionic strength of the medium by adding different concentrations of $\mathrm{NaCl}$ and $\mathrm{CaCl}_{2}$ to the crude

\begin{tabular}{|c|c|c|c|c|c|c|c|c|}
\hline Alcohol & $\begin{array}{c}\text { Salt } \\
\text { species }\end{array}$ & $\begin{array}{c}\text { Salt } \\
\begin{array}{c}\text { Concentration } \\
(\mathrm{mol} / \mathrm{L})\end{array} \\
\end{array}$ & $\begin{array}{c}\begin{array}{c}\text { Ionic strength } \\
(\mathrm{mol} / \mathrm{L})\end{array} \\
\end{array}$ & $\begin{array}{c}\text { Total protein } \\
(\mathrm{mg} / \mathrm{mL})\end{array}$ & $\begin{array}{l}\text { Total activity } \\
\quad(\mathrm{U} / \mathrm{mL})\end{array}$ & $\begin{array}{l}\text { Specific } \\
\text { activity } \\
(\mathrm{U} / \mathrm{mg})\end{array}$ & $\begin{array}{c}\text { Activity } \\
\text { yield }(\%)\end{array}$ & $\begin{array}{c}\text { Purification } \\
\text { factor }\end{array}$ \\
\hline$*$ & $*$ & $*$ & $*$ & 0.238 & 25.6 & 107.6 & 100 & 1.0 \\
\hline n-propyl & $\mathrm{NaCl}$ & 0.05 & 0.15 & 0.165 & 52.2 & 315.1 & 81.5 & 2.9 \\
\hline n-propyl & $\mathrm{NaCl}$ & 0.10 & 0.20 & 0.155 & 50.4 & 323.8 & 78.8 & 3.0 \\
\hline n-propyl & $\mathrm{NaCl}$ & 0.50 & 0.60 & 0.098 & 50.0 & 516.6 & 78.1 & 4.8 \\
\hline$*$ & $*$ & $*$ & $*$ & 0.331 & 20.7 & 62.6 & 100 & 1.0 \\
\hline iso-propyl & $\mathrm{NaCl}$ & 0.05 & 0.15 & 0.216 & 51.3 & 236.2 & 98.5 & 3.8 \\
\hline iso-propyl & $\mathrm{NaCl}$ & 0.10 & 0.20 & 0.232 & 52.5 & 227.2 & 101.3 & 3.6 \\
\hline iso-propyl & $\mathrm{NaCl}$ & 0.50 & 0.60 & 0.200 & 46.6 & 232.6 & 89.8 & 3.7 \\
\hline$*$ & $*$ & $*$ & $*$ & 0.228 & 15.4 & 67.4 & 100 & 1.0 \\
\hline n-propyl & $\mathrm{CaCl}_{2}$ & 0.05 & 0.25 & 0.205 & 46.4 & 226.4 & 120.7 & 3.3 \\
\hline n-propyl & $\mathrm{CaCl}_{2}$ & 0.10 & 0.40 & 0.175 & 45.1 & 257.3 & 117.4 & 3.8 \\
\hline n-propyl & $\mathrm{CaCl}_{2}$ & 0.50 & 1.60 & 0.199 & 21.4 & 107.6 & 55.6 & 1.6 \\
\hline$*$ & $*$ & $*$ & $*$ & 0.234 & 17.3 & 74.3 & 100 & 1.0 \\
\hline iso-propyl & $\mathrm{CaCl}_{2}$ & 0.05 & 0.25 & 0.237 & 43.6 & 183.4 & 100.7 & 2.5 \\
\hline iso-propyl & $\mathrm{CaCl}_{2}$ & 0.10 & 0.40 & 0.222 & 56.2 & 253.3 & 129.8 & 3.4 \\
\hline iso-propyl & $\mathrm{CaCl}_{2}$ & 0.50 & 1.60 & 0.228 & 52.1 & 229.6 & 120.4 & 3.1 \\
\hline
\end{tabular}
enzyme extract followed by the precipitation with the alcohol.

*Refers to the results of the crude enzyme extract. 
In the runs using $\mathrm{CaCl}_{2}$, most of the concentrations of the salt resulted in activity yields higher than $100 \%$. Using this salt, yields lower than $100 \%$ were observed at $\mathrm{CaCl}_{2}$ concentration of $0.50 \mathrm{~mol} / \mathrm{L}$, using n-propyl alcohol. The highest yields were observed using $\mathrm{CaCl}_{2}$ and iso-propyl alcohol $(0.10$ and 0.50 $\mathrm{mol} / \mathrm{L}$, respectively) or n-propyl alcohol $(0.05 \mathrm{~mol} / \mathrm{L})$.

The increase in the activity yields could be due to the selective precipitation of the inulinase after salt addition, which occurs with a lower inhibitor aggregation. The use of salts, such as ammonium sulfate, is frequently cited in the literature in enzyme recovery, resulting in an increase of enzymatic activities (Silva et al. 2011, Gill et al. 2006).

The salt concentration showed a trend observed for almost all solvents. Initially an increase in the activity yield is observed, followed by a decrease of this response when salt concentration is further increased to $0.5 \mathrm{~mol} / \mathrm{L}$. This trend clearly shows the need for an optimization of this process variable.

Runs performed in parallel using the two tested solvents at concentrations higher than $2.0 \mathrm{~mol} / \mathrm{L}$ resulted in an instant protein precipitation. However, a total loss of enzyme activity was detected.

Considering the purification factors, all runs using salts resulted in PF higher than 2.4-fold, reference value since it was also achieved using ethanol (data not shown). It is worth to mention that when $0.5 \mathrm{~mol} / \mathrm{L}$ of $\mathrm{NaCl}$ and n-propyl alcohol were tested, a PF of 4.8-fold was observed.

The PF and yields obtained in our study are comparable or higher than the ones presented in the current literature. Li et al. (2012) obtained a PF of 3.4 and a yield of $51.1 \%$ after purification of an endo-inulinase using DEAE-Sepharose Fast Flow chromatography. Zhang et al. (2009) achieved a PF of 2.53 and a yield of $46 \%$, for purification of a recombinant inulinase using affinity chromatography (Zhang et al. 2009). Other authors presented a PF of 3.75 and a yield of $62.48 \%$ using HiTrap Butyl Sepharose 4 FF combined to ultrafiltration for purification of a $\beta$-fructofuranosidase (Jedrzejczak-Krzepkowska et al. 2011). In this way, results presented in our study shows a great potential of application of the proposed method as a simple and low cost purification strategy.

\section{CONCLUSIONS}

This study proposed a strategy for purification of inulinase produced by solid state fermentation, using two low cost techniques based on changing the ionic strength of the crude enzymatic extract, followed by precipitation using n-propyl or iso-propyl alcohol. The PF was increased to 2.4-fold depending on the alcohol concentration and feed flow rate used. This process resulted in enzyme activation, probably due to removal of inhibitors.

Results showed that a PF of 4.8 -fold and a yield of $78.1 \%$ were achieved after the change in the ionic strength followed by precipitation. These results are very promising when compared to the ones currently presented in the literature, especially the chromatographic ones, showing that enzyme purification using simple and low costs techniques could be more powerful than other more costly methods.

\section{ACKNOWLEDGMENTS}

The authors would like to thank Coordenação de Aperfeiçoamento de Pessoal de Nível Superior (CAPES), Conselho Nacional de Desenvolvimento Científico e Tecnológico (CNPq) and Fundação de Amparo à Pesquisa do Estado do Rio Grande do Sul (FAPERGS) for financial support. 


\section{REFERENCES}

ABU EL-SOUOD SM, MOHAMED TM, ALI TMM, EL-BADRY MO AND EL-KEIY MEJ. 2014. Partial purification of extracellular exo-inulinase from Ulocladium atrum. J Gen Eng Biotechnol 12: 15-20.

BENDER JP, MAZUTTI MA, DI LUCCIO M AND TREICHEL H. 2008. Extraction of inulinase obtained by solid state fermentation of sugarcane bagasse by Kluyveromyces marxianus NRRL Y-7571. Appl Biochem Biotech 149: 195-203.

BOERIS V, ROMANINI D, FARRUGGIA B AND PICO G. 2009. Purification of chymotrypsin from bovine pancreas using precipitation with a strong anionic polyelectrolyte. Process Biochem 44: 588-592.

BRADFORD MM. 1976. A Rapid and Sensitive Method for the Quantitation of Microgram Quantities of Protein Utilizing the Principle of Protein-Dye Binding. Anal Biochem 72: 248-254.

CAZETTA ML, MARTINS PMM, MONTI R AND CONTIERO J. 2005. Yacon (Polymnia sanchifolia) extract as a substrate to produce inulinase by Kluyveromyces marxianus var. bulgaricus. J Food Eng 66: 301-305.

CORTEZ EB AND PESSOA JR A. 1999. Xylanase and $\beta$-xylosidase separation by fractional precipitation. Process Biochem 35: 277-283.

GILL PK, MANHAS RK AND SINGH P. 2006. Purification and properties of a heat-stable exoinulinase isoform from Aspergillus fumigatus. Bioresource Technol 97: 894-902.

GOLUNSKI S, ASTOLFI V, CARNIEL N, OLIVEIRA D, DI LUCCIO M, MAZUTTI MA AND TREICHEL H. 2011. Ethanol precipitation and ultrafiltration of inulinases from Kluyveromyces marxianus. Sep Purif Technol 78: 261-265.

JEDRZEJCZAK-KRZEPKOWSKA M, TKACZUK KL AND BIELECKI S. 2011. Biosynthesis, purification and characterization of -fructofuranosidase from Bifidobacterium longum KN29.1. Process Biochem 46: 963-1972.

LI Y, LIU G, WANG K, CHI Z AND MADZAK C. 2012. Overexpression of the endo-inulinase gene from Arthrobacter sp. S37 in Yarrowia lipolytica and characterization of the recombinant endo-inulinase. J Mol Catal B-Enzym 74: 109-115.

MAZUTTI MA, BENDER JP, DI LUCCIO M AND TREICHEL H. 2006. Optimization of inulinase production by solid state fermentation using sugarcane bagasse as substrate. Enzime and Microbial Technol 39: 56-59.

MAZUTTI M, CENI G, DI LUCCIO M AND TREICHEL H. 2007. Production of inulinase by solid-state fermentation: effect of process parameters on production and preliminary characterization of enzyme preparations. Bioprocess and Biosystems Eng 30: 297-304.

MAZUTTI M, ZABOT G, BONI G, SKOVRONSKI A, OLIVEIRA D AND DI LUCCIO M. 2010. Inulinase production by solidstate fermentation in a packed-bed bioreactor. Food Chem 120: 163-173.

MILLER GL. 1959. Use of dinitrosalisylic acid reagent for determination of reducing sugar. Anal Chem 31: 426-428.

PRZYBYCIEN TM, PUJAR NS AND STEELE LM. 2004. Alternative bioseparation operations: life beyond packed-bed chromatography. Curr Opin Biotech 15: 469-478.

SGUAREZI C, LONGO C, CENI G, BONI G, SILVA MF, DI LUCCIO M, MAZUTTI MA, MAUGERI F, RODRIGUES MI AND TREICHEL H. 2008. Inulinase production by agroindustrial residues: acid pretreatment of substrates and optimization of production. Food Bioprod Process 2: 409-414.

SILVA MF, FREIRE DMG, CASTRO AM, DI LUCCIO M, MAZUTTI MA, OLIVEIRA JV, TREICHEL H AND OLIVEIRA D. 2011. Concentration, Partial Characterization, and Immobilization of Lipase Extract from P. brevicompactum by Solid-State Fermentation of Babassu Cake and Castor Bean Cake. Appl Biochem Biotech 164: 755-766.

SINGH RS AND CHAUHAN K. 2017. Inulinase production from a new inulinase producer, Penicillium oxalicum BGPUP-4. Biocatal Agric Biotechnol 9: 1-10.

SINGH RS, SINGH RP AND KENNEDY JF. 2017. Immobilization of yeast inulinase on chitosan beads for the hydrolysis of inulin in a batch system. Int J Biol Macromol 95: 87-93.

SINGH RS, SOOCH BS AND PURI M. 2007. Optimization of medium and process parameters for the production of inulinase from a newly isolated Kluyveromyces marxianus YS-1. Bioresource Technol 98: 2518-2525.

SOARES PAG, VAZA AFM, CORREIA MTS, PESSOA JR A AND CARNEIRO-DA-CUNHA MG. 2012. Purification of bromelain from pineapple wastes by ethanol precipitation. Sep Pur Technol 98: 389-395.

TRENTINI MMS, TONIAZZO G, ZENI J, PILI J, DI LUCCIO M AND VALDUGA E. 2015. Purification of pectinases from Aspergillus niger ATCC 9642 by ethanol precipitation. Biocatal Agric Biotechnol 4: 315-320.

ZHANG L, ZHAO C, ZHU D, OHTA Y AND WANGA Y. 2004. Purification and characterization of inulinase from Aspergillus niger AF10 expressed in Pichia pastoris. Protein Expres Purif 35: 272-275.

ZHANG T, GONG F, PENG Y AND CHI Z. 2009. Optimization for high-level expression of the Pichia guilliermondii recombinant inulinase in Pichia pastoris and characterization of the recombinant inulinase. Process Biochem 44: 1335-1339.

ZHAO M, MU B, JIANG L, ZHOU T, ZHANG Z, LU Z, JIN R AND YANG R. 2011. Purification and characterization of inulin fructotransferase (DFA III-forming) from Arthrobacter aurescens SK 8.001. Bioresource Technol 102: 1757-1764. 
